International Journal of Oceanography and Hydrobiology Volume 50, No. 3, September 2021

\title{
First record of straight-needle pteropod Creseis acicula Rang, 1828 bloom in the Çanakkale Strait (NE Aegean Sea, Turkey)
}

by

\section{Sezginer Tunçer ${ }^{1, *}$, Nazik Öğretmen ${ }^{2, * *}$, Fikret Çakır ${ }^{3}$, Alkan Öztekin ${ }^{3}$, Ayhan Oral $^{4}$, Salih Can Suner ${ }^{5}$}

\section{DOI: 10.2478/oandhs-2021-0026 \\ Category: Original research paper \\ Received: November 30, 2020 \\ Accepted: February 1, 2021}

'Department of Marine Biology, Faculty of Marine Science and Technology, Çanakkale Onsekiz Mart University, 17100, Çanakkale, Turkey

${ }^{2}$ Climate Geochemistry Department, Max Planck Institute for Chemistry, 55128, Mainz, Rheinland-Pfalz, Germany

${ }^{3}$ Department of Fishing and Fish Processing Technology Çanakkale Onsekiz Mart University, Faculty of Marine Science and Technology, 17100, Çanakkale, Turkey

${ }^{4}$ Department of Chemistry, Faculty of Science and Arts, Çanakkale Onsekiz Mart University, Çanakkale, Turkey

${ }^{5}$ Department of Chemistry and Chemical Processing Technologies, Lapseki Vocational School, Çanakkale Onsekiz Mart University, Lapseki, Çanakkale, Turkey

Corresponding author: *stuncer@comu.edu.tr; **n.ogretmen@mpic.de

\section{Abstract}

Pteropods are marine pelagic calcifier mollusks sensitive to chemical changes in seawater due to their highly soluble aragonite shells. Increased acidity (reduced $\mathrm{pH}$ ) of seawater causes difficulties in precipitating their shells and/or results in their dissolution, which is related to increased atmospheric $\mathrm{CO}_{2}$ concentrations and warming of seawater. They are therefore indicators of environmental changes. In this paper, we present the first record of the straightneedle pteropod Creseis acicula Rang, 1828 bloom in the surface waters of the Çanakkale Strait, Turkey (NE Aegean Sea), encountered in July 2020, when the highest sea surface temperatures and $\mathrm{pH}$ levels since 2007 were recorded. In coastal zones, such as the Çanakkale Strait, anthropogenic activity contributes significantly to environmental changes. Consequently, the increase in $\mathrm{pH}$ at elevated temperatures indicates an auxiliary factor (i.e. anthropogenic activity) that triggered the $C$. acicula bloom, rather than global atmospheric $\mathrm{CO}_{2}$ levels.

Key words: Creseis acicula, pteropod, Çanakkale Strait, marine ecology, bloom, anthropogenic impact 


\section{Introduction}

Pteropods, one of the common members of marine zooplankton assemblages, are pelagic holoplanktic mollusks that spend their entire life cycle in the water column (Lalli \& Gilmer 1989; Peijnenburg et al. 2020). They play an important role in the marine food web as they are a major food source for other marine organisms such as sea whales, seabirds, and commercially exploited fish (Lalli \& Gilmer 1989; Manno et al. 2017).

The name "pteropod" in Greek means wing-foot (ptero $=$ wing; poda $=$ foot). Pteropods can be shelled or unshelled. Thecosomatous (mucus-web feeders; sea butterflies), i.e. shelled pteropods grow their shells from calcium carbonate $\left(\mathrm{CaCO}_{3}\right)$ derived from seawater in which they live. Therefore, they belong to marine calcifiers together with planktic foraminifers and coccolithophores, and contribute $20-42 \%$ to the global calcite budget (Bednaršek et al. 2012; Buitenhuis et al. 2019; Lischka et al. 2018). Different from other marine calcifiers, their shells are composed of aragonite - a meta form of $\mathrm{CaCO}_{3}$, which is $50 \%$ more soluble in water than its calcite form (Fabry et al. 2008). When seawater is undersaturated with aragonite due to ocean acidification (reduced $\mathrm{pH}$ ), shelled pteropods have difficulty building their shells and/or the shells may dissolve (Fabry 1990; Fabry et al. 2009; Manno et al. 2017). Although the waters of the Mediterranean Region are supersaturated both with calcite and aragonite, and such acidification is not expected at least until the end of the 21st century, studies report a decrease in carbonate ion saturation compared to the pre-industrial era (Krasakopoulou et al. 2017; Schneider et al. 2007).

The Mediterranean Sea is a climate change hot spot, whose climate responds to global change (Giorgi 2006; Lejeusne et al. 2010) and suffers from adverse anthropogenic impact due to the fact that it is a landlocked sea (Hassoun et al. 2015; Touratier \& Goyet 2011). In this context, the Çanakkale Strait (Dardanelles) is a biological corridor between the Black Sea-Marmara Sea and Aegean-Mediterranean Sea realms (Aydin et al. 2015), where fresh waters of the Black Sea dominate in its upper layer, and saline waters of the Mediterranean origin occupy its deeper water column below 20-40 m. Furthermore, the presence of thermophilic Mediterranean species in the cooler, northernmost parts of the Aegean Sea and the Sea of Marmara indicates the impact of climate change and warming of seawater (Tunçer et al. 2020a,b; Yapıcı et al. 2016). These findings are also consistent with the reports on the Mediterraneanization of the inland Sea of Marmara and the Black Sea (TÜDAV 2020). Warming of seawater and increased inflow of water originating from the Mediterranean Sea through the Çanakkale and Istanbul straits into the Sea of Marmara and the Black Sea suggest changes in the marine ecosystem allowing acclimatization of Mediterranean species to their new environment (Oğuz \& Öztürk 2015; Öztürk 2002). Therefore, reporting any unusual occurrence and/or bloom of marine organisms plays an important role in monitoring environmental changes.

The holoplanktic gastropod C. acicula encountered in the Çanakkale Strait is a circumglobal species, occurring worldwide from open ocean to coastal environments, living in warm waters with sea surface temperatures (SSTs) between 10 and $28^{\circ} \mathrm{C}$ and salinity between 30 and $41 \mathrm{PSU}$, including hypersaline environments such as the Red Sea (Almogi-Labin 1982; Angulo-Campillo et al. 2011; Bé \& Gilmer 1977; Comeau et al. 2012; Dai et al. 2020; Lalli \& Gilmer 1989; López-Arellanes et al. 2018; Parra-Flores \& Gasca 2009; Pillai \& Rodrigo 1979; Sakthivel \& Harida 1974). It is abundant in tropical and subtropical regions between $45^{\circ} \mathrm{N}$ and $40^{\circ} \mathrm{S}$ of all oceans and commonly encountered in active current systems and coastal areas (Bé \& Gilmer 1977). It prefers waters between 10 and $100 \mathrm{~m}$ and migrates to the sea surface during the night (Menzies 1957). In warm waters of Japan, Florida and Trieste (NE Italy), C. acicula is responsible for "sea stings" causing marine dermatitis, in other words, "sea bather's eruption" (Hutton 1960; Kokelj et al. 1994; Nishimura 1965).

The occurrence and abundance of this species in the northwestern Mediterranean Sea have been previously addressed (Comeau et al. 2012; Howes et al. 2017). In September 1975, a sudden swarm of C. acicula in the surface waters of the Ligurian Sea in NW Italy was reported (Albergoni 1975). In July 1990, its presence was detected when sea bathers complained about intense itching during and after bathing, and exceptionally high salinities were recorded on the same day in the Gulf of Trieste, NE Italy (Kokelj et al. 1994).

Its occurrence along the Turkish coast was reported from the Gulf of Iskenderun (Akyüz 1957; Çevik et al. 2006; Gökalp 1972; Gücü et al. 1991), the coast of Izmir (Onmus 2002), and the southwestern coast of the Aegean Sea (Okuş et al. 2004), and confirmed as such in the updated list of marine mollusks published in 2014 (Öztürk et al. 2014).

In this study, Creseis acicula Rang, 1828 (= Creseis clava) was sampled from the surface water $(0.5 \mathrm{~m})$ of the Çanakkale Strait (NW Turkey) in the summer season of 2020. The study area was sampled seasonally between 2007 and 2018 as part of the Marmara Environmental Monitoring (MAREM) Project (Artüz 
et al. 2007, 2009, 2011a,b, 2012, 2013, 2014, 2015, 2016, 2018 , 2019), which will hereinafter be referred to as "MAREM reports". According to these reports, even though fossil C. acicula was found in small numbers in core sediments recovered from the northern part of the Çanakkale Strait, it was not present in the water column. In this study, we present the first data on a C. acicula bloom in this region, comparing previous and recent marine environmental parameters (sea surface temperature, dissolved oxygen, salinity and $\mathrm{pH}$ ) along with nutrient and chlorophyll- $a$ data. We interpret this bloom as a response to reduced anthropogenic impact on marine habitats in the Çanakkale Strait during COVID-19 lockdowns. We report the first record of a C. acicula bloom not only in the Çanakkale Strait waters, but also in the Turkish waters, along with marine physicochemical and biochemical parameters.

\section{Study area}

The Çanakkale Strait (Dardanelles), part of the Turkish Straits System, is a $75 \mathrm{~km}$ long corridor with
Table 1

Average monthly number of vessels transiting the Istanbul and Çanakkale straits between April and July of each year from 2017 to 2020

\begin{tabular}{|l|l|l|l|l|}
\hline \multicolumn{1}{|c|}{ Region } & 2017 & 2018 & 2019 & 2020 \\
\hline Çanakkale Strait & 3728 & 3751 & 3599 & 3384 \\
\hline Istanbul Strait & 3566 & 3500 & 3363 & 3134 \\
\hline
\end{tabular}

a width of more than $0.7 \mathrm{~km}$ and a sill depth of $55 \mathrm{~m}$, connecting the Black Sea with the North Aegean Sea through the Marmara Sea (Jarosz et al. 2012; Oğuz 2015; Fig. 1). It plays an important role in domestic and international marine traffic (Table 1). At present, a two-layer water exchange occurs through the Dardanelles Strait in the form of outflow from the Black Sea and inflow from the Mediterranean Sea (Sayin et al. 2011). The Black Sea Waters (BSW), with low salinity ( $18 \mathrm{PSU})$ and temperature of $\sim 16-17^{\circ} \mathrm{C}$, reach salinity around 30 PSU after being modified on their way through the Marmara Sea, where they occupy 20-40 $\mathrm{m}$ of the surface layer of the water column. They then

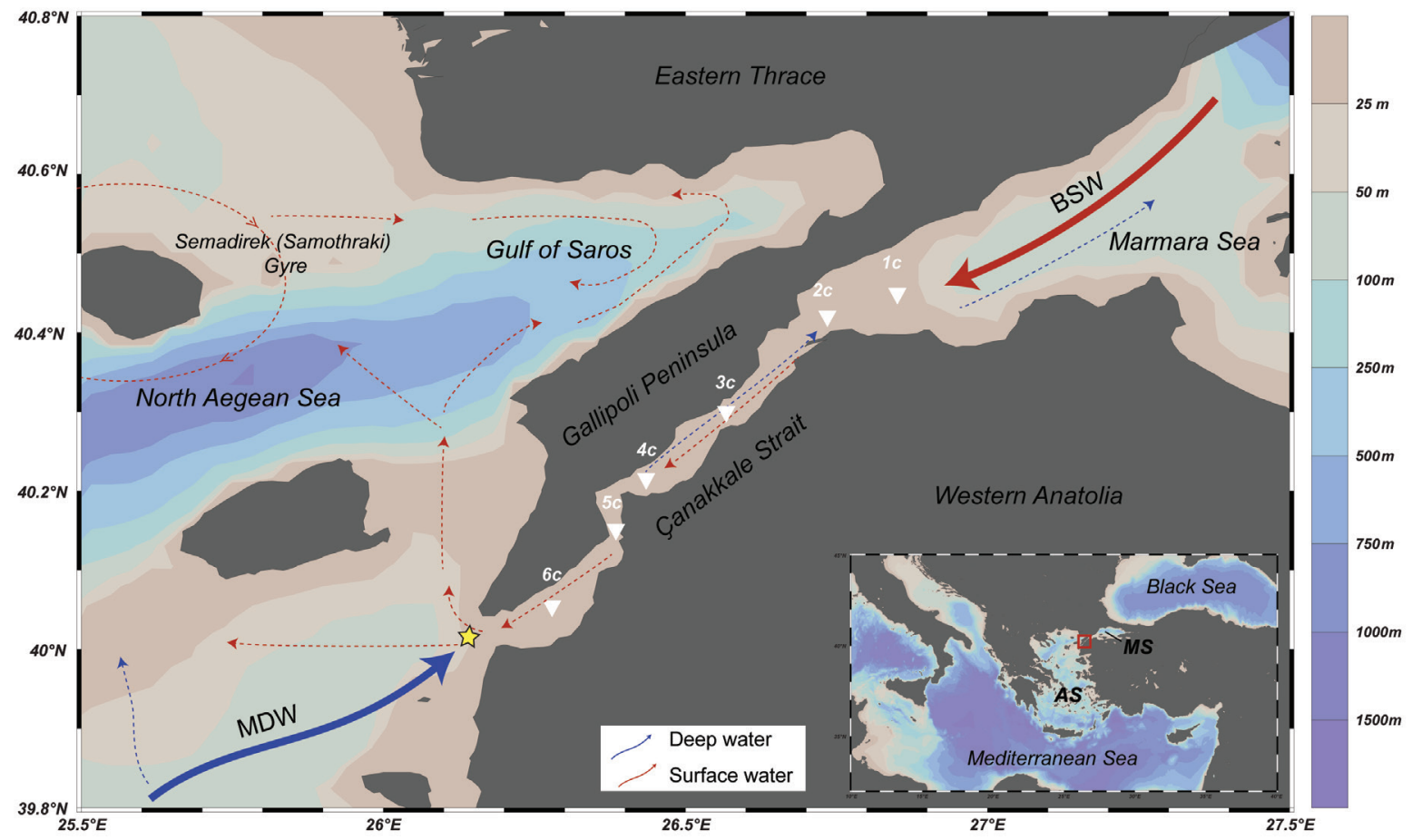

\section{Figure 1}

Location map showing the present-day simplified hydrography of the region. White triangles indicate sampling sites from 1c to 6c; yellow star - location of nutrient concentration data; BWS - Black Sea Water; MDW - Mediterranean Deep Water; MS - Marmara Sea; AS - Aegean Sea. The dark grey area represents the surrounding land. The map produced using Ocean Data View (Schlitzer 2018). 
enter the Aegean Sea through the Dardanelles, join the Samothraki (Semadirek) Gyre of the North Aegean domains and fill the Gulf of Saros (Pazi 2008; Fig. 1). The maximum depth of the Çanakkale Strait is around $100 \mathrm{~m}$. Below 20-40 m, waters originating from the Levantine Basin in the Eastern Mediterranean Sea form the intermediate and deep waters (Mediterranean Deep Water; MDW) of the adjacent seas, joining the Marmara Sea (Beşiktepe et al. 1994; Türkoçlu et al. 2006; Zervakis et al. 2003). The MDW in the study area consists of two components: the Levantine Intermediate Water (LIW) and the North Aegean Deep Water (NADW). A mixture of LIW and BSW occupies the water depths of $40-100 \mathrm{~m}$, and the LIW extends to $100-400 \mathrm{~m}$ with a temperature of $\sim 14-15^{\circ} \mathrm{C}$ and salinity around 38 PSU. On the other hand, the NADW occupies the water column below $400 \mathrm{~m}$ with a temperature of about $13^{\circ} \mathrm{C}$ and salinity 39 PSU (Pazi 2008).

\section{Materials and methods}

Sampling was carried out during the time interval of $18.40-19.00$ on 20 July 2020 , when there was still sunlight. Samples of C. acicula examined in this study were collected during an expedition on R/V Bilim I, which was planned for studies of microplastics in the Çanakkale Strait at site $6 \mathrm{c}\left(40^{\circ} 06^{\prime} 50^{\prime \prime} \mathrm{N} ; 26^{\circ} 21^{\prime} 21^{\prime \prime} \mathrm{E}\right.$; Fig. 1). Of all sampling sites in the Çanakkale Strait, $6 c$ is the only site where C. acicula was encountered in July 2020, and a symbiont species was not observed. Moreover, according to data in the MAREM reports, C. acicula was not detected at the same locations along the Çanakkale Strait (Fig. 1; sampling sites from 1c to 6c) during previous sampling seasons (winters and summers) between 2007 and 2018.

Sampling was conducted using a manta trawl net (Ryan et al. 2009), equipped with a $60 \times 20 \mathrm{~cm}$ frame with a trawl length of $260 \mathrm{~cm}$ and a mesh size of 333

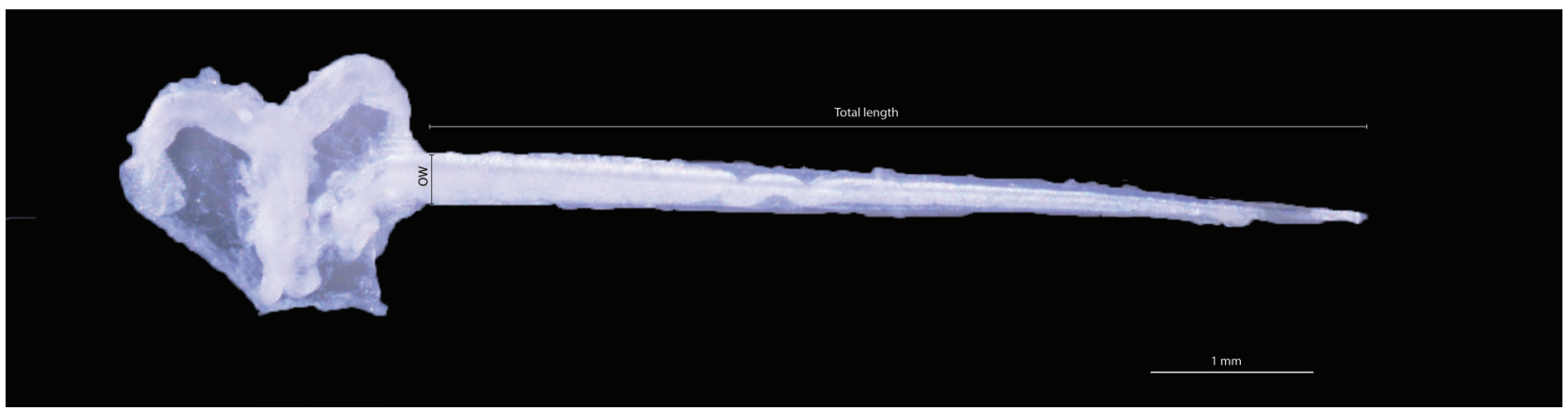

\section{Figure 2}

Light microscope photo of a specimen showing the total length and operculum width (OW)

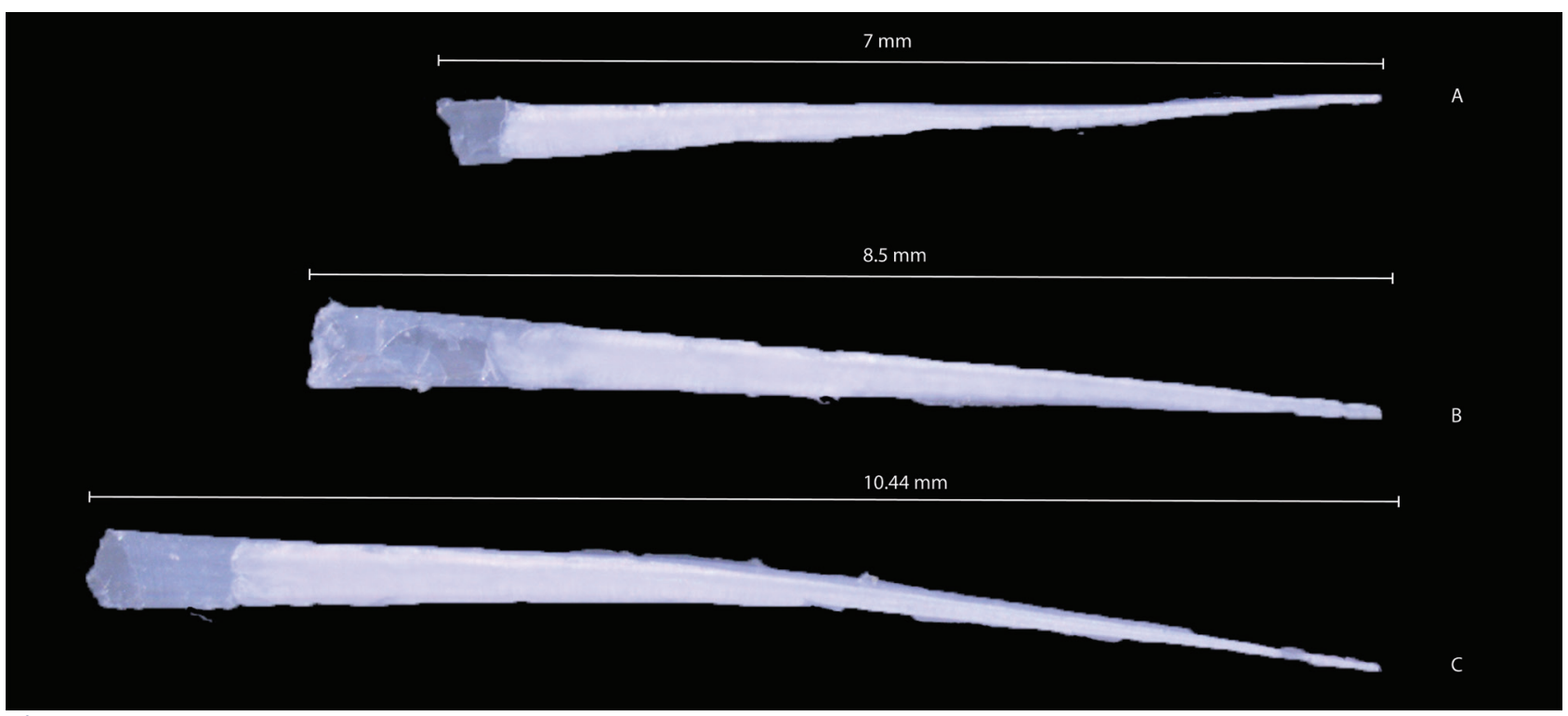

Figure 3

Examples of measured specimens with their total length. A) juvenile form; B) mature form and C) adult form 
$\mu \mathrm{m}$. Oblique trawls were run at a water depth of $0.5 \mathrm{~m}$ attached to the shipboard for $20 \mathrm{~min}$ at a speed set at 2 knots. Hydrobios Mechanical Flow Meter 438110 was used to quantify the water filtered by the manta net.

A total of $9.63 \mathrm{~m}^{3}$ seawater was filtered and 22243 individuals of C. acicula were counted (Fig. 2). All specimens were collected into clean glass beakers and fixed in 5\% formaldehyde solution, and then transported to the Faculty of Marine Sciences and Technology, Department of Marine Sciences and Limnology, Çanakkale Onsekiz Mart University, Turkey for further qualitative and quantitative analysis. The collected material was examined and identified following the previous studies (Lalli \& Gilmer 1989; van der Spoel \& Dadon 1999). Specimens were classified as juvenile, mature and adult based on their lengths. Juvenile forms were considered $<7.0 \mathrm{~mm}$, mature forms between 7.01 and $9 \mathrm{~mm}$, and adult forms $>9$ mm (Fig. 3). To identify adult and mature individuals, the operculum width and total length of individuals were measured for their morphological characteristics (Fig. 2; Table 2) using a binocular microscope. Photos were taken using a Carl Zeiss SZX 16 microscope. We applied the analysis of variance test to explain the variation in the data (i.e. morphological characteristics) within the regression model (Fig. 4). We used this information to discuss whether physicochemical conditions played an important role in morphological characteristics of the collected specimens by comparing our data with the previous report (Roger et al. 2002).

\subsection{Marine environmental parameters}

Marine environmental parameters (sea surface temperature, salinity, dissolved oxygen and $\mathrm{pH}$ ) of the sampling locations were determined using a CTD device. The parameters were compared with previous

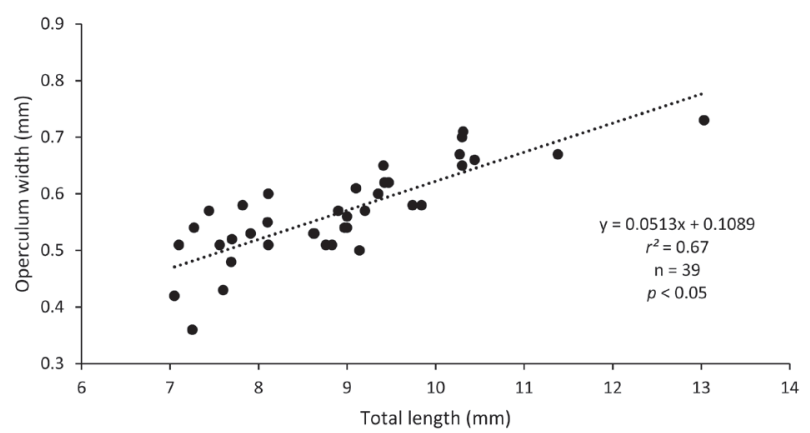

Figure 4

Operculum width and total length of 39 individuals showing a strong correlation by the quadratic formula at $r^{2}=0.67$.
Table 2

Total length and operculum width of 39 individuals

\begin{tabular}{|c|c|c|}
\hline Sample & Total length (mm) & Operculum width $(\mathrm{mm})$ \\
\hline 1 & 7.05 & 0.42 \\
\hline 2 & 7.1 & 0.51 \\
\hline 3 & 7.25 & 0.36 \\
\hline 4 & 7.27 & 0.54 \\
\hline 5 & 7.44 & 0.57 \\
\hline 6 & 7.56 & 0.51 \\
\hline 7 & 7.6 & 0.43 \\
\hline 8 & 7.69 & 0.48 \\
\hline 9 & 7.69 & 0.48 \\
\hline 10 & 7.7 & 0.52 \\
\hline 11 & 7.82 & 0.58 \\
\hline 12 & 7.91 & 0.53 \\
\hline 13 & 8.1 & 0.55 \\
\hline 14 & 8.11 & 0.51 \\
\hline 15 & 8.11 & 0.6 \\
\hline 16 & 8.62 & 0.53 \\
\hline 17 & 8.63 & 0.53 \\
\hline 18 & 8.76 & 0.51 \\
\hline 19 & 8.83 & 0.51 \\
\hline 20 & 8.9 & 0.57 \\
\hline 21 & 8.97 & 0.54 \\
\hline 22 & 9 & 0.54 \\
\hline 23 & 9 & 0.56 \\
\hline 24 & 9.1 & 0.61 \\
\hline 25 & 9.14 & 0.5 \\
\hline 26 & 9.2 & 0.57 \\
\hline 27 & 9.35 & 0.6 \\
\hline 28 & 9.41 & 0.65 \\
\hline 29 & 9.42 & 0.62 \\
\hline 30 & 9.47 & 0.62 \\
\hline 31 & 9.74 & 0.58 \\
\hline 32 & 9.84 & 0.58 \\
\hline 33 & 10.27 & 0.67 \\
\hline 34 & 10.3 & 0.7 \\
\hline 35 & 10.30 & 0.65 \\
\hline 36 & 10.31 & 0.71 \\
\hline 37 & 10.44 & 0.66 \\
\hline 38 & 11.38 & 0.67 \\
\hline 39 & 13.03 & 0.73 \\
\hline Average & 8.87 & 0.56 \\
\hline Min. & 7.05 & 0.36 \\
\hline Max & 13.03 & 0.73 \\
\hline$S D$ & 1.28 & 0.08 \\
\hline
\end{tabular}

measurements conducted in the same region during the Marmara Sea Environmental Monitoring (MAREM) Project between 2007 and 2018 (Fig. 5; see MAREM reports). Pearson correlation analysis was applied to detect possible correlations between the variables (Table 3). The correlation analysis includes the dataset for the period between 2008 and 2018, excluding 2007 due to data availability at sampling site $6 c$, which is the focus of this study. 

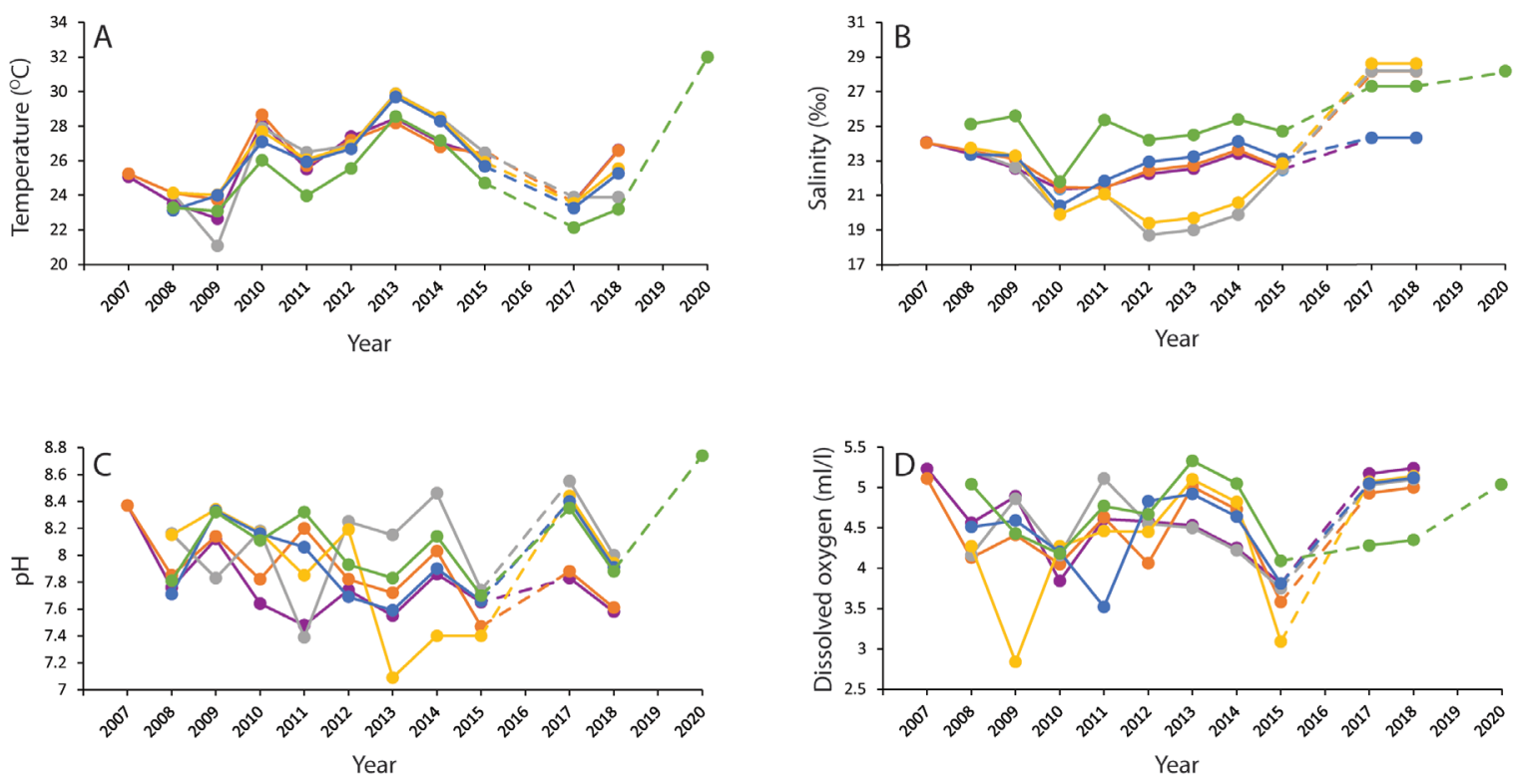

Stations: $\rightarrow-1 c \rightarrow-2 c \rightarrow 3 c \rightarrow-4 c \rightarrow 5 c \rightarrow 6 c$

\section{Figure 5}

Plots of the marine environmental parameters measured during the summer seasons (July-August) each year between 2007 and 2020 at six sites (from 1c to 6c) along the Çanakkale Strait. Dashed lines indicate no measurement. Data retrieved from MAREM reports.

\subsection{Nutrients and Chlorophyll-a}

Table 3

Physicochemical parameters (temperature, salinity, $\mathrm{pH}$ and dissolved oxygen) measured at site $6 \mathrm{c}$ in the Çanakkale Strait during summer seasons from 2008 to 2020 ( $n=11$; significant correlation at $p<0.05$ level) showing no significant Pearson correlation.

\begin{tabular}{|c|c|c|c|c|}
\hline Parameter & SST & Sal & pH & DO \\
\hline SST & 1 & & & \\
\hline$p$ & - & & & \\
\hline Sal & 0.07 & 1 & & \\
\hline$p$ & 0.85 & - & & \\
\hline$p H$ & 0.35 & 0.49 & 1 & 1 \\
\hline$p$ & 0.29 & 0.13 & - & - \\
\hline$p$ & 0.57 & 0.15 & 0.11 & 1 \\
\hline DO & 0.07 & 0.65 & 0.75 & - \\
\hline
\end{tabular}

Nitrogen is one of the most important nutrients regulating the primary production of phytoplankton, which are grazed by zooplankton (Bristow et al. 2017; Sitta et al. 2018). In the study area, nitrate $\left(\mathrm{NO}_{3}^{-}\right)$, i.e. the inorganic form of nitrogen, is found in higher concentrations compared to other nutrient sources such as nitrite and phosphate (Tuğrul et al. 2002). To investigate changes in nutrient concentrations, monthly mean nitrate values obtained using the MedBFM (Mediterranean Sea Biogeochemistry Analysis and Forecast) model system were examined for the period from April 2017 to December 2020 (Fig. 6) and compared with chlorophyll-a concentrations (Figs 7 and 8).

Chlorophyll-a (Chl-a) is the major photosynthetic pigment of phytoplankton living in aquatic environments, and is considered the most suitable proxy for phytoplankton biomass studies related to primary production (Huot et al. 2007), which is affected by nutrient supply, i.e. nitrate concentration in seawater (Cermeño et al. 2016). Therefore, it gives us an insight into biochemical variability in the vicinity of the sampling site $6 \mathrm{c}$ (Figs 7 and 8 ).

The data used in this study were derived from monthly and daily interpolated Chl- $a$ concentrations 


\section{6}
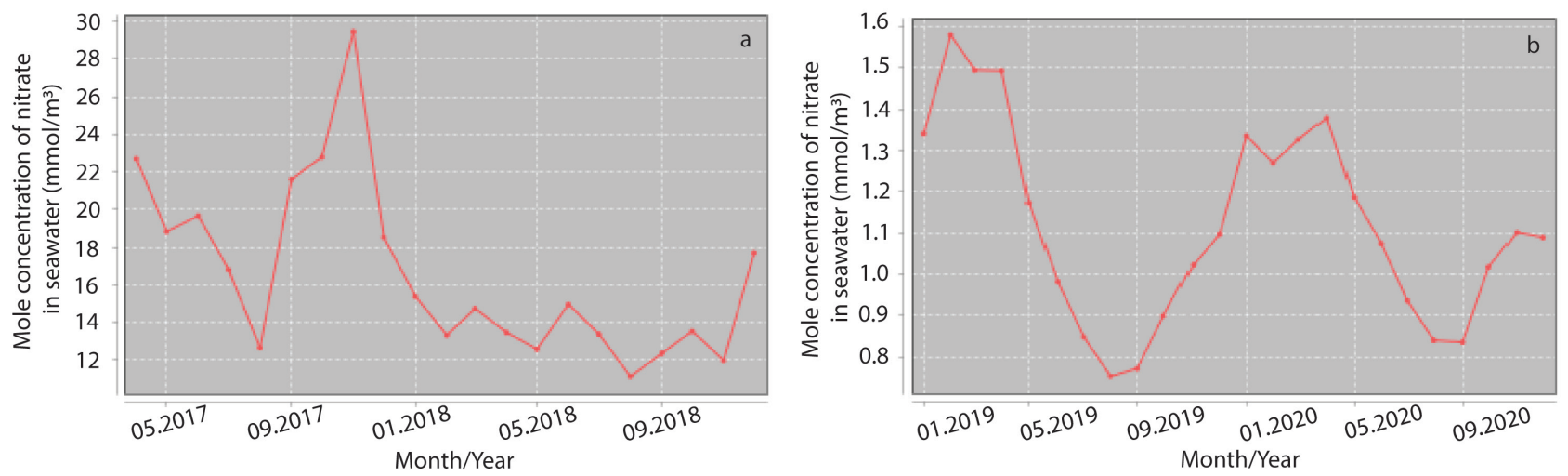

Figure 6

Monthly average nitrate concentrations as a nutrient proxy from the Sea of Marmara and the Northern Aegean Sea for the time interval between (a) April 2017 and December 2018; and (b) January 2019 and December 2020. Please note different scales of the two plots. Data retrieved from https://marine.copernicus.eu/
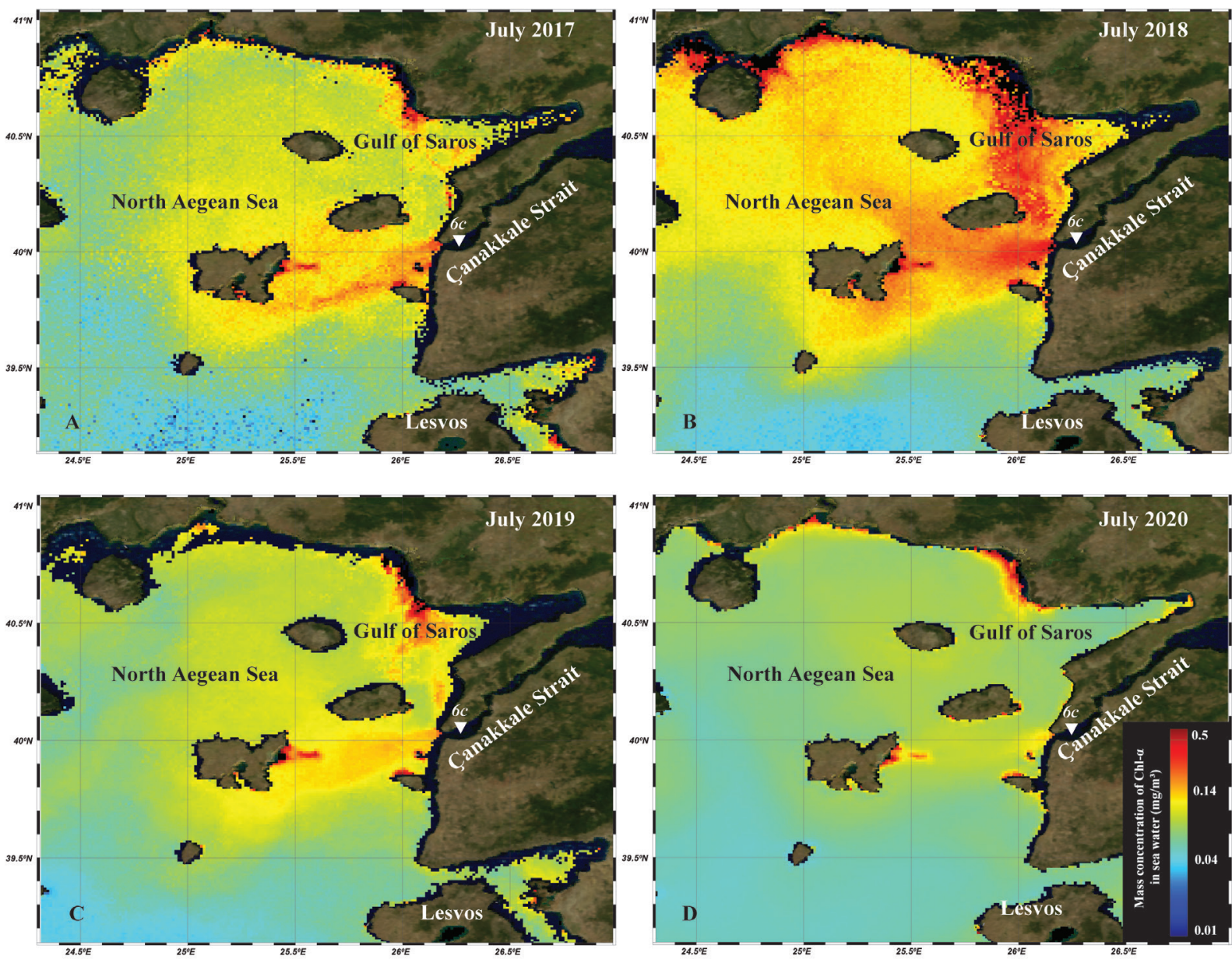

\section{Figure 7}

Interpolated Chl- $a$ concentration maps for July in the period between 2017 and 2020 at the vicinity of sampling site $6 c$ in the Çanakkale Strait. The color scale bar applies to all the maps. Data retrieved from https://marine.copernicus.eu/ 


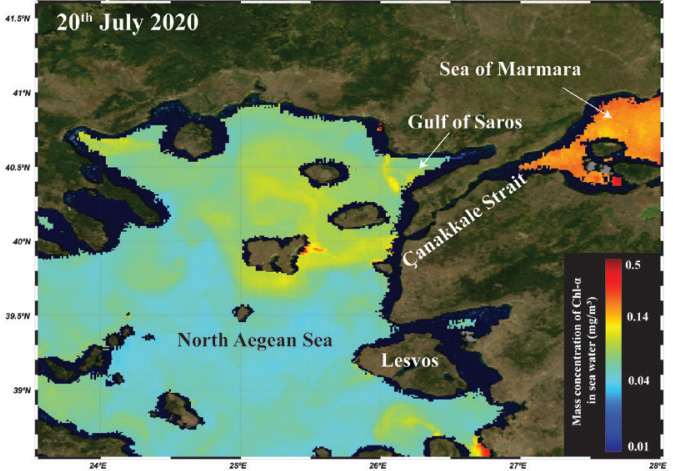

Figure 8

Map showing Chl-a concentrations observed on the sampling day, 20 July 2020, in the vicinity of sampling site $6 c$ in the Çanakkale Strait and the Sea of Marmara. Data retrieved from https://marine.copernicus.eu/

in the Mediterranean Sea obtained from multi-satellite and Sentinel-3 OLCl observations distributed by the Global Ocean Satellite monitoring and marine ecosystem study group of the Italian National Research Council in Rome.

Both datasets (nitrate and Chl- $a$ concentrations) can be accessed via the online platform of the E.U. Copernicus Marine Service (https://marine.copernicus. $\mathrm{eu} /$ ).

\section{Results}

\subsection{Length and operculum width of specimens}

Thirty-nine adult and mature individuals were measured for their morphological characteristics such as their total length and operculum width (Fig. 2, Fig. 3 and Table 2). Even though the juvenile forms were not included in the measurements, their occurrence with adult forms indicates a bloom event.

The length of the specimens varied between 7.05 and $13.03 \mathrm{~mm}$ and their operculum width varied between 0.36 and $0.73 \mathrm{~mm}$. The regression analysis applied to test the correlation trend of the total length and the operculum width of the 39 measured specimens showed that they significantly correlate at $r^{2}$ $=0.67$ with $p<0.05$ (Fig. 5), indicating that $67 \%$ of the variation can be explained by these two explanatory variables.

\subsection{Marine environmental parameters}

Marine environmental parameters represent physicochemical conditions of the marine habitat in which organisms thrive. To investigate changes between previous and recent marine conditions, we have compared our measurements with data detailed in the MAREM reports from 2007 to 2018. We have restricted our comparison to the upper $0.5 \mathrm{~m}$ layer of surface water, where C. acicula blooms were observed in July 2020. We considered salinity, temperature, $\mathrm{pH}$ and dissolved oxygen values to analyze the environment of $C$. acicula blooms.

Sea surface temperatures (SSTs) measured at all sampling sites each year yield similar values, except for 2020 (Fig. 5a). SSTs at site 1c shows fluctuations between 22 and $28^{\circ} \mathrm{C}$; site $2 \mathrm{c}$ between 23 and $28^{\circ} \mathrm{C}$; site $3 \mathrm{C}$ shows the largest variations from 21 to $29^{\circ} \mathrm{C}$; site $4 \mathrm{C}$ from 23.5 to $29^{\circ} \mathrm{C}$; site $5 \mathrm{C}$ between 23 and $29.5^{\circ} \mathrm{C}$, and site $6 \mathrm{c}$ between 22 and $28.5^{\circ} \mathrm{C}$, with the highest temperature of $32^{\circ} \mathrm{C}$ measured in July 2020 (Fig. 5a).

Salinity values show fluctuations at each site (Fig. 5b). Site 1c shows variations between 21 and 24 PSU; site 2c between 21 and 28 PSU; site 3c and 4c between 19 and 28 PSU; site 5c from 20 to 24 PSU and site $6 \mathrm{c}$ from 4 to 28 PSU except for one measurement in 2010, which results in $22 \mathrm{PSU}$ (Fig. 5b).

The $\mathrm{pH}$ measurements show large variations at each site each year (Fig. $5 \mathrm{c}$ ). The $\mathrm{pH}$ values at sites $1 \mathrm{c}$ and 2 c range from 7.5 to 8.4 ; at site 3 c from 7.4 to 8.5 ; at site $4 \mathrm{c}$ from 7.1 to 8.4 ; at site $5 \mathrm{c}$ from 7.6 to 8.4 , and site $6 \mathrm{c}$ shows the highest values ranging from 7.7 to 8.7 , with the highest value of 8.7 measured in July 2020 .

Dissolved oxygen (DO) values, except for those measured at site 4c in 2009 and site 5c in 2011, show a similar trend (Fig. $5 \mathrm{~d}$ ). DO at site $1 \mathrm{c}$ varies between 3.8 and $5.2 \mathrm{ml} \mathrm{l}^{-1}$; at site 2c between 3.6 and 5.1 $\mathrm{mmol} \mathrm{mol}{ }^{-1}$; at site $3 \mathrm{c}$ between 3.7 and $5.1 \mathrm{mmol} \mathrm{mol}^{-1}$; at site $5 \mathrm{c}$ between 3.5 and $5.1 \mathrm{mmol} \mathrm{mol}^{-1}$ and at site $6 \mathrm{c}$ between 4.2 and $5.3 \mathrm{mmol} / \mathrm{mol}$, with the highest average value of $4.6 \mathrm{mmol} \mathrm{mol}^{-1}$ (Fig. $5 \mathrm{~d}$ ).

Pearson's correlation results indicate no significant correlation at $p<0.05$ between the physicochemical parameters (Table 3 ), suggesting an auxiliary variable inducing changes in the marine ecosystem of the study area.

\subsection{Nutrient and Chl-a concentrations}

The study area is characterized by fluctuating nutrient concentrations each season depending on the nutrient supply from the surrounding rivers and/or the two-layer water exchange system in the Çanakkale Strait (Fig. 6; Türkoğlu et al. 2006). From April 2017 to December 2018, it was represented by nitrate concentrations ranging from $\sim 10$ to $30 \mathrm{mmol} \mathrm{m}^{-3}$, with the highest values corresponding to spring and autumn-winter seasons. In April 2017, a concentration 
of $\sim 23 \mathrm{mmol} / \mathrm{m}^{3}$ was recorded, steadily decreasing through August 2017 (Fig. 6a). The highest values were recorded between September and November 2017, showing a sharp decrease in January 2017, and from January 2017 until November 2018, showing a slight increase in December 2018 (Fig. 6a). No marked increase in nitrate concentrations was observed in spring of 2018.

From January 2019, on the other hand, these values dropped to the levels between $\sim 0.6$ and 1.6 mmol $\mathrm{m}^{-3}$ (Fig. 6b). Between February and March 2019, high peaks in nutrient concentrations of 1.5 to $1.6 \mathrm{mmol} \mathrm{m}^{-3}$ were recorded, corresponding to the highest values between January 2019 and December 2020. Nitrate concentration values steadily decreased between April 2019 and August 2019, with the lowest values $<0.8 \mathrm{mmol} \mathrm{m}^{-3}$. Concentration values showed an increase from September 2019 through April 2020, with fluctuating but high values between January 2020 and April 2020, which corresponds to the second peak interval between January 2019 and December 2020 (Fig. 6b). After April 2020, nitrate concentrations decreased again until September 2020 to values between 0.8 and $0.9 \mathrm{mmol} \mathrm{m}^{-3}$. July 2020, i.e. the sampling period of this study, falls within this range of decreasing nutrient concentrations with values slightly above $0.9 \mathrm{mmol} \mathrm{m}^{-3}$. After September 2020, they were increasing again until December 2020.

Chl- $a$ concentration maps prepared for July from 2017 to 2020 demonstrate a parallel outcome to nitrate concentrations (Figs $6 \mathrm{a}$ and 6b), with higher values in July 2017 and July 2018, and lower values in July 2019 and July 2020 (Fig. 7). The years 2017 and 2018 were marked with higher $\mathrm{Chl}-a$ concentrations, with values in the range of $0.3-0.4 \mathrm{mg} \mathrm{m}^{-3}$, while values in July 2019 and July 2020 were around $0.1 \mathrm{mg} \mathrm{m}^{-3}$.

Interestingly, on the sampling day, the Sea of Marmara was characterized by a high nitrate concentration of about $0.3 \mathrm{mg} \mathrm{m}^{-3}$, which was not the case for the vicinity of the sampling area, where even lower values, i.e. below $0.1 \mathrm{mg} \mathrm{m}^{-3}$, were recorded (Fig. $8 ; 20$ July 2020).

\section{Discussion}

\subsection{Varying environmental parameters, morphological tolerance and blooms}

Morphological characteristics of pteropods depend on environmental parameters, such as dwarfing in size may be advantageous to increase the survival under stressed conditions (e.g. global warming, increased ocean acidity; Garilli et al. 2015; Roger et al. 2002).
The only available study involving measurements of total length and operculum width in specimens of $C$. acicula was conducted off the Australian coast, and it indicates a correlation between these two morphological features at $r^{2}=0.85$ (Roger et al. 2002). In our study, on the other hand, specimens correlate at $r^{2}=0.67(n=39 ; p<0.05)$. The total length of specimens reported in the study cited above ranged from 5 to $25 \mathrm{~mm}$, and the operculum width ranged from 0.3 to $1.4 \mathrm{~mm}$ (Roger et al. 2002).

In comparison, Australian coasts are characterized by the following parameters: SSTs around $28^{\circ} \mathrm{C}$, sea surface salinity around $\sim 35 \mathrm{PSU}, \mathrm{pH}$ around 8.07 , and DO around $4.5 \mathrm{ml} \mathrm{I}^{-1}$ (CSIRO 2018; Locarnini et al. 2019; Zweng et al. 2019). On the other hand, site $6 \mathrm{c}$ in the Çanakkale Strait, where C. acicula was found in July 2020, was characterized by the following values: SST $32^{\circ} \mathrm{C}$, salinity - $28 \mathrm{PSU}, \mathrm{pH}-8.7$ and $\mathrm{DO}-5.05 \mathrm{ml} \mathrm{I}^{-1}$. Even though the correlation details for total length and operculum width were not provided, the SSTs during the outbreak in Daya Bay varied between 29.8 and $32.8^{\circ} \mathrm{C}$ and salinity was $>30$ PSU (Dai et al. 2020), which is higher than salinity values measured in July 2020 in the Çanakkale Strait. Similarly, during the C. acicula swarm in the southern Indian waters, the salinity was above 31 PSU (Pillai \& Rodrigo 1979). Although it is difficult to infer due to scarcity of comparable data, it may be possible to consider salinity as a potential controlling factor for the growth pattern of C. acicula. Nonetheless, because $C$. acicula is one of the most common species in the subtropics and tropics (Bé \& Gilmer 1977), a further study is needed to clarify the response of the growth pattern in C. acicula to physicochemical parameters of the surrounding waters.

The bloom, on the other hand, may have occurred as a result of a combination of several parameters. Site $6 \mathrm{c}$, despite its proximity to warmer Aegean waters, shows lower SSTs compared to other sites along the Çanakkale Strait due to freshwater inflow from rivers (Türkoğlu et al. 2006). However, 20 July 2020 was characterized by a $9^{\circ} \mathrm{C}$ increase in ambient SST, from $23^{\circ} \mathrm{C}$ (in 2018) to $32^{\circ} \mathrm{C}$ (Fig. 5a). For comparison, high SST was also measured in the 2013 summer season (Fig. 5a). SST was $\sim 28^{\circ} \mathrm{C}$, but salinity was $24.5 \mathrm{PSU}$, and $\mathrm{pH}$ was 7.83 (Figs $5 \mathrm{a}, 5 \mathrm{~b}$ and $5 \mathrm{c}$, respectively). Even though DO was relatively high $\left(5.33 \mathrm{ml} \mathrm{l}^{-1}\right.$; Fig. 5d), C. acicula was not found during sampling when physicochemical parameters were measured (Artüz et al. 2014), suggesting that DO may not be a factor controlling C. acicula blooms.

Since C. acicula was previously reported from the Southeastern Aegean waters and the Izmir coast, one can consider the possibility of a latitudinal 
migration of C. acicula associated with the improved surrounding seawater conditions sufficient to thrive. This theory would explain the monospecific bloom of this species. Other pelagic mollusk species, such as Limacina helicina in cold waters, were reported to migrate poleward as the temperature of surface ocean water increases (Comeau et al. 2012). Similarly, since $C$. acicula prefers warm and saline environments, increased SST due to global warming and increased salinity in the Çanakkale Strait along with increased $\mathrm{pH}$ levels may have triggered the migration of $C$. acicula from the Southern Aegean Sea to the northern coasts (Çanakkale Strait), which provide a suitable ecosystem for a bloom.

\subsection{Nutrient supply and Chlorophyll-a}

One important factor, in addition to physicochemical parameters, is the nutrient supply for a marine organism to thrive. The unique bloom of C. acicula that occurred in mid-July 2020 in the South China Sea was associated with the heavy rainfall season (Dai et al. 2020). Given its adaptability, C. acicula may have tolerated large salinity fluctuations recorded during the outbreak season due to heavy rainfall, which was considered to have provided an increased food supply and contributed to elevated Chl- $a$ (Dai et al. 2020).

In comparison, nutrient concentrations in the study area may show seasonal fluctuations up to $10-15$ times (Fig. 6; Türkoğlu 2010), which is strongly affected by the two-layer water exchange system formed by warm, highly saline Mediterranean deep water and cooler, less saline surface water originating from the Black Sea as explained in Section 2. Nutrients in the surface water of the Black Sea to a depth of 20-40 m are mostly taken up within the Sea of Marmara, before they reach the Çanakkale Strait (Türkoğlu 2010), and the rest are dispersed in the Northeastern Aegean Sea, joining the surface currents (Figs 1 and 8 ).

It has been suggested that nutrient enrichment observed in different periods other than seasonal variations may be related to vertical mixing between the surface waters and nutrient-rich, oxygenated, saline waters of the Mediterranean Sea as they enter the Çanakkale Strait (Tuğrul et al. 2002; Türkoğlu 2010). However, in 2017 and 2018, monthly nitrate concentrations were $>10 \mathrm{mmol} \mathrm{m}^{-3}$ (Fig. 6a), whereas in 2019 and 2020, these values fluctuated between 0.6 and $1.6 \mathrm{mmol} \mathrm{m}^{-3}$ and were slightly above 0.9 mmol $\mathrm{m}^{-3}$ in July 2020 (Fig. 6b). The high Chl-a concentration in the Sea of Marmara, observed on the day of sampling (20 July 2020), did not continue through the Çanakkale Strait (Fig. 8), which may indicate nutrient uptake by phytoplankton and/or other marine organisms. This finding contradicts the food availability theory proposed for the outbreak recorded in Daya Bay, indicating a different controlling factor.

\subsection{Increased $\mathrm{pH}$ and $\mathrm{DO}$ in response to reduced marine traffic in the Çanakkale Strait}

Researchers suggest that despite increased anthropogenic $\mathrm{CO}_{2}$ concentrations, the Northern Aegean waters are not expected to be affected by carbonate ion depletion as they are supersaturated with both calcite and aragonite (Krasakopoulou et al. 2017). Interestingly, elevated $\mathrm{pH}$ and DO levels measured during the July 2020 sampling (Fig. 5c) indicate reduced acidity contradicting the statements regarding declining $\mathrm{pH}$ levels, elevated temperatures and $\mathrm{pCO}_{2}$ on a global scale (Gruber 2011). Correspondingly, the simultaneous increase in these parameters (Figs $5 c$ and $5 \mathrm{~d}$ ) may be related to reduced $\mathrm{CO}_{2}$ emissions during the COVID-19 lockdowns between April and July 2020, reflecting reduced acidity in response to reduced greenhouse gas emissions, which most likely provided a suitable environment for these aragonite-shelled organisms to thrive.

The reduced $\mathrm{CO}_{2}$ values in the first half of 2020 corresponding to COVID-19 lockdowns have been recently reported (Le Quéré et al. 2020; Liu 2020), and the Ministry of Environment and Urbanization of Turkey has reported a $17.4 \%$ daily reduction in greenhouse gas emissions at the country level during the COVID-19 restrictions (Gündoğmuş 2020). The daily reduction in greenhouse gas emissions in Turkey was estimated at $0.8 \%$ (9510 tons of $\mathrm{CO}_{2}$ ) on 21 January 2020, and reached $17.4 \%$ (210 429 tons of $\mathrm{CO}_{2}$ ) on 30 April 2020. In coastal areas, where the maritime transport sector operates, shipping emissions have been reported to contribute to GHG emissions, accounting for part of anthropogenic emissions (Winnes et al. 2015). Interestingly, in the region of the Sea of Marmara, $68 \%$ of the shipping emissions in the Turkish Straits are emitted in the Çanakkale Strait (Deniz \& Durmuşoğlu 2008; Durmuşoğlu 2013).

According to the statistics obtained from the Directorate General of Maritime Commerce, the Ministry of Transport and Infrastructure of Turkey (https://atlantis.udhb.gov.tr), a total of 3692 and 3476 vessels respectively passed through the Çanakkale and Istanbul straits between April and July of 2017, 2018 and 2019 (Table 1). In 2020, a total of 3134 vessels from the Istanbul Strait and 3384 vessels from the Çanakkale Strait were recorded between April and July (Table 1), suggesting a decrease by $\sim 10 \%$. Consequently, the 
reduced domestic and international marine traffic in the Çanakkale Strait may have contributed to the reduction of greenhouse gas emissions along with the reduction of $\mathrm{CO}_{2}$ release to surface waters, optimizing $\mathrm{pH}$ and dissolved oxygen levels in the sea surface waters for the bloom to occur.

\section{Conclusions}

This study reports the first occurrence and bloom of C. acicula Rang, 1828 in the Northeast Aegean Sea (Çanakkale Strait, Turkey) observed in July 2020. We presented the first detailed data on morphological characteristics of $C$. acicula specimens collected along the Turkish coast together with measured marine environmental parameters. We further interpreted the possible causes that may have favored this first monospecific bloom of C. acicula. Our findings indicate a reduced anthropogenic impact in the waters of the Çanakkale Strait following reduced maritime traffic during the COVID-19 lockdowns along with generally increased SSTs. Given that C. acicula is one of the most common pteropod species in the tropics and subtropics, including the Mediterranean Region, it is important to expand our knowledge of this species due to its abundance as it serves as an indicator of environmental change. Our study emphasizes the importance of systematic seasonal sampling and data collection to investigate the effects of the interaction between climate change and anthropogenic contribution in sensitive marine ecosystems.

\section{Funding}

This research was funded by Çanakkale Onsekiz Mart University-Scientific Research Projects (BAP), grant No. 2019-2986.

\section{Conflicts of Interest}

The authors declare no conflict of interest.

\section{Author Contribution}

ST and NÖ designed and conceptualized this research. ST, FÇ, AÖ, AO and SCS conducted the fieldwork. ST and $F C$ performed sample measurements. ST, NÖ, FÇ and AÖ accomplished data collection. NÖ completed data analysis with important inputs from ST and AÖ. NÖ visualized the results and wrote the original manuscript. All authors contributed to the discussion and editing of the manuscript.

\section{Acknowledgements}

Special thanks to D. Anıl Odabaşı, G. Erman Uğur, Osman Odabaşı, Umut Tuncer and the crew of R/V BILIM I. We are thankful to Şimal Özen for providing us with the maritime vessel statistics. The authors gratefully acknowledge the anonymous reviewer whose comments helped to improve the manuscript. We thank Dr. Anna Dziubińska for editorial handling and Ewa Kaźmierczak for language improvement.

\section{References}

Akyüz, E.F. (1957). Observations on the Iskenderun red mullet (Mullus barbatus) and its environment. GFCM Proceedings and Technical Papers 4: 305-326.

Albergoni, A. (1975). Addensamento improvviso di Creseis acicula (Rang, 1828) (Gastropoda, Pteropoda) in una baia del Mare Ligure. Conchiglie 11(11-12), 233-236.

Almogi-Labin, A. (1982). Stratigraphic and paleoceanographic significance of Late Quaternary pteropods from deep-sea cores in the Gulf of Aqaba (Elat) and northernmost Red Sea. Marine Micropaleontology 7(1): 53-72. DOI: 10.1016/03778398(82)90015-9.

Angulo-Campillo, O., Aceves-Medina, G. \& Avedaño-lbarra, R. (2011). Holoplanktonic mollusks (Mollusca: Gastropoda) from the Gulf of California, México. Check List 7(3): 337. DOI: 10.15560/7.3.337.

Artüz L.M., Artüz, O.B., Aydemir, A., Sönmez, B., Özel, D. et al. (2007). Marmara Sea Environmental Monitoring Project Data For the Year 2007 (Preliminary Reports): 2007 JulyAugust Summer Season Oceanographic-HydrographicBiological-Chemical-Sedimentological Station Studies. In L.M Artüz (Ed.). T.C. Istanbul Kültür University Press No: 1. (In Turkish).

Artüz L.M., Artüz, O.B., Gülen, D., Torcu-Koç, H., Üzen, E. et al. (2009). Marmara Sea Environmental Monitoring Project Data For the Year 2008 (Preliminary Reports): 2008 Winter and Summer Season Oceanographic-Hydrographic-BiologicalChemical-Sedimentological Station Studies. In L.M. Artüz (Ed.). T.C. Piri Reis University Press No: 1. (In Turkish).

Artüz, L.M., Aydin, A., Gülen, D., Torcu-Koç, H., Artüz, O.B. et al. (2011a). Marmara Sea Environmental Monitoring Project Data For the Year 2009 (Preliminary Reports): 2009 Winter and Summer Season Oceanographic-HydrographicBiological-Chemical-Sedimentological Station Studies. In L.M. (Ed.). Marmara University Press No: 799. (In Turkish).

Artüz, L.M., Gülen, D., Aydin, A., Torcu-Koç, H., Artüz, O.B. et al. (2011b). Marmara Sea Environmental Monitoring 
Project Data For the Year 2010 (Preliminary Reports): 2010 Winter and Summer Season Oceanographic-HydrographicBiological-Chemical-Sedimentological Station Studies. In L.M. Artüz (Ed.). Marmara University Press No: 800. (In Turkish).

Artüz, L.M., Aydin, A., Gülen, D., Yalcin, B., Artüz, O.B. et al. (2012). Marmara Sea Environmental Monitoring Project Data For the Year 2011 (Preliminary Reports): 2011 Winter and Summer Season Oceanographic-Hydrographic-BiologicalChemical-Sedimentological Station Studies. In L.M. Artüz (Ed.). Marmara University Press No: 803. (In Turkish).

Artüz, L.M., Gülen, D., Aydin, A., Yalcin, B., Artüz, O.B. et al. (2013). Marmara Sea Environmental Monitoring Project Data For the Year 2012 (Preliminary Reports): 2012 Winter and Summer Season Oceanographic-HydrographicBiological-Chemical-Sedimentological Station Studies. In L.M. Artüz (Ed.). AK-Kim Chemistry Industry and Trade Inc. Press. (In Turkish).

Artüz, L.M., Artüz, O.B., Gürseler, G., Gülen, D., Sakinc, M. et al. (2014). Marmara Sea Environmental Monitoring Project Data For the Year 2013 (Preliminary Reports): 2013 Winter and Summer Season Oceanographic-HydrographicBiological-Chemical-Sedimentological Station Studies. In L.M. Artüz (Ed.). Union of Bars of Turkey Press No: 252. (In Turkish).

Artüz, L.M., Artüz, O.B., Gürseler, G., Gülen, D., Sakinc, M. et al. (2015). Marmara Sea Environmental Monitoring Project Data For the Year 2014 (Preliminary Reports): 2014 Winter and Summer Season Oceanographic-HydrographicBiological-Chemical-Sedimentological Station Studies. In L.M. Artüz (Ed.). Union of Bars of Turkey Press No: 280. (In Turkish).

Artüz, L.M., Artüz, O.B., Gürseler, G., Gülen, D., Sakinc, M. et al. (2016). Marmara Sea Environmental Monitoring Project Data For the Year 2015 (Preliminary Reports): 2015 Winter and Summer Season Oceanographic-HydrographicBiological-Chemical-Sedimentological Station Studies. In L.M. Artüz (Ed.). Union of Bars of Turkey Press No: 314. (In Turkish).

Artüz, L.M., Artüz, O.B., Gülen, D., Sakinc, M., Yalcin, B. et al. (2018). Marmara Sea Environmental Monitoring Project Data For the Year 2017 (Preliminary Reports): 2017 Winter and Summer Season Oceanographic-HydrographicBiological-Chemical-Sedimentological Station Studies. In L.M. Artüz (Ed.). Union of Bars of Turkey Press. (In Turkish).

Artüz, L.M., Artüz, O.B., Gülen, D., Sakinc, M., Yalcin, B. et al. (2019). Marmara Sea Environmental Monitoring Project Data For the Year 2018 (Preliminary Reports): 2018 Winter and Summer Season Oceanographic-HydrographicBiological-Chemical-Sedimentological Station Studies. In L.M. Artüz (Ed.). Union of Bars of Turkey Press. (In Turkish).

Aydin, H., Balci, M., Uzar, S. \& Balkis, N. (2015). Dinoflagellate cyst assemblages in surface sediments of southwestern Black Sea and Çanakkale Strait (Dardanelles). Fresenius
Environmental Bulletin 24(12C): 4789-4798.

Bé, A.W.H. \& Gilmer, R.W. (1977). A Zoogeographic and Taxonomic Review of Euthecosomatous Pteropoda, Volume 1. In A.T.S. Ramsay (Ed.), Oceanic Micropaleontology (pp. 733-808). Academic Press.

Bednaršek, N., Mozina, J., Vogt, M., O'Brien, C. \& Tarling, G.A. (2012). The global distribution of pteropods and their contribution to carbonate and carbon biomass in the modern ocean. Earth System Science Data 4(1): 167-186. DOI: 10.5194/essd-4-167-2012.

Beşiktepe, Ş.T., Sur, H.İ., Özsoy, E., Latif, M. A., Oğuz, T. et al. (1994). The circulation and hydrography of the Marmara Sea. Progress in Oceanography 34(4): 285-334. DOI: 10.1016/0079-6611(94)90018-3.

Bristow, L. A., Mohr, W., Ahmerkamp, S. \& Kuypers, M.M.M. (2017). Nutrients that limit growth in the ocean. Current Biology27(11):R474-R478.DOI:10.1016/j.cub.2017.03.030.

Buitenhuis, E.T., Le Quéré, C., Bednaršek, N. \& Schiebel, R. (2019). Large Contribution of Pteropods to Shallow $\mathrm{CaCO}_{3}$ Export. Global Biogeochemical Cycles 33(3): 458-468. DOI: 10.1029/2018GB006110.

Cermeño, P., Chouciño, P., Fernández-Castro, B., Figueiras, F.G., Marañón, E. et al. (2016). Marine primary productivity is driven by a selection effect. Frontiers in Marine Science 3(SEP). DOI: 10.3389/fmars.2016.00173.

Çevik, C., Kideys, A., Toklu, B., Ergüden, D. \& Sarihan, E. (2006). New pelagic gastropoda species encountered on the Turkish coast of the Levant Sea. Turkish Journal of Veterinary and Animal Sciences 30(2): 151-157.

Comeau, S., Gattuso, J.P., Jeffree, R. \& Gazeau, F. (2012). Effect of carbonate chemistry manipulations on calcification, respiration, and excretion of a Mediterranean pteropod. Biogeosciences Discussions 9(5): 6169-6189. DOI: 10.5194/ bgd-9-6169-2012.

Comeau, S., Gattuso, J.P., Nisumaa, A.M. \& Orr, J. (2012). Impact of aragonite saturation state changes on migratory pteropods. Proceedings of the Royal Society B: Biological Sciences 279(1729): 732-738. DOI: 10.1098/rspb.2011.0910.

CSIRO. (2018). State of the Climate 2018 - CSIRO-BOM-Dec2018.

Dai, M., Qi, Z., Zeng, L., Zhang, S., Wang, L. et al. (2020). An unprecedented outbreak of pelagic molluscs Creseis acicula in Daya Bay, South China Sea. Authorea: 1-7. DOI: 10.22541/au.159809490.05151881.

Deniz, C. \& Durmuşoğlu, Y. (2008). Estimating shipping emissions in the region of the Sea of Marmara, Turkey. Science of the Total Environment 390(1): 255-261. DOI: 10.1016/j.scitotenv.2007.09.033.

Durmuşoğlu, Y. (2013). Damage Costs of Air Pollution from Ships in the Region of the Sea of Marmara. Naval Engineers Journal 125(3): 71-85.

Fabry, V.J. (1990). Shell growth rates of pteropod and heteropod molluscs and aragonite production in the open ocean: implications for the marine carbonate system. Journal of Marine Research 48(1): 209-222. DOI: 
$10.1357 / 002224090784984614$.

Fabry, V.J., McClintock, J.B., Mathis, J.T, \& Grebmeier, J.M. (2009). Ocean acidification at high latitudes: The Bellwether. Oceanography 22(SPL.ISS. 4): 160-171. DOI: 10.5670/ oceanog.2009.105.

Fabry, V.J., Seibel, B.A., Feely, R.A. \& Orr, J.C. (2008). Impacts of ocean acidification on marine fauna and ecosystem processes. ICES Journal of Marine Science 65: 414-432. DOI: 10.2307/j.ctv8jnzw1.25.

Garilli, V., Rodolfo-Metalpa, R., Scuderi, D., Brusca, L., Parrinello, D. et al. (2015). Physiological advantages of dwarfing in surviving extinctions in high- $\mathrm{CO}_{2}$ oceans. Nature Climate Change 5(7): 678-682. DOI: 10.1038/nclimate2616.

Giorgi, F. (2006). Climate change hot-spots. Geophysical Research Letters 33(8): 1-4. DOI: 10.1029/2006GL025734.

Gökalp, N. (1972). Comparative analysis of the plankton situation of Edremit, Bodrum and İskenderun Bays. Pub. of the Hydrobiol. Research. Inst. 3: 71. (In Turkish).

Gruber, N. (2011). Warming up, turning sour, losing breath: Ocean biogeochemistry under global change. Philosophical Transactions of the Royal Society A: Mathematical, Physical and Engineering Sciences 369(1943): 1980-1996. DOI: 10.1098/rsta.2011.0003.

Gücü, A.C., Bingel, F.\&Ünsal, M. (1991).Zooplankton sopulation and its time series in the Northern Cilician Basin-Turkish Coast. Turkish Journal of Zoology 15: 202-210.

Gündoğmuş, Y.N. (2020). Coronavirus restictions resulted in reduced greenhouse gas emissions. Anadolu Haber Ajansı. https://www.aa.com.tr/tr/turkiye/koronavirus-tedbirlerisera-gazi-emisyonunu-azaltti/1861782. (In Turkish).

Hassoun, A.E.R., Gemayel, E., Krasakopoulou, E., Goyet, C., Abboud-Abi Saab, M. et al. (2015). Acidification of the Mediterranean Sea from anthropogenic carbon penetration. Deep Sea Research Part l: Oceanographic Research Papers 102: 1-15. DOI: 10.1016/j.dsr.2015.04.005.

Howes, E.L., Eagle, R.A., Gattuso, J.P. \& Bijma, J. (2017). Comparison of Mediterranean pteropod shell biometrics and ultrastructure from historical (1910 and 1921) and present day (2012) samples provides baseline for monitoring effects of global change. PLOS ONE 12(1): 1-23. DOI: 10.1371/journal.pone.0167891.

Huot, Y., Babin, M., Bruyant, F., Grob, C., Twardowski, M.S. (2007). Relationship between photosynthetic parameters and different proxies of phytoplankton biomass in the subtropical ocean. Biogeosciences 4(5): 853-868. DOI: 10.5194/bg-4-853-2007.

Hutton, R.F. (1960). Marine Dermatosis. Archives of Dermatology 82(6): 951. DOI: $10.1001 /$ archderm.1960.01580060107017.

Jarosz, E., Teague, W.J., Book, J.W. \& Beiktepe, Ş.T. (2012). Observations on the characteristics of the exchange flow in the Dardanelles Strait. Journal of Geophysical Research: Oceans 117(11) 1-18. DOI: 10.1029/2012JC008348.

Kokelj, F., Milani, L., Lavaroni, G. \& Casaretto, L. (1994). Marine dermatitis due to Creseis acicula. J. Eur. Acad. Dermatol.
Venereol. 3: 555-561. DOI: 10.1111/j.1468-3083.1994. tb00420.x.

Krasakopoulou, E., Souvermezoglou, E., Giannoudi, L. \& Goyet, C. (2017). Carbonate system parameters and anthropogenic $\mathrm{CO}_{2}$ in the North Aegean Sea during October 2013. Continental Shelf Research 149(October 2013): 69-81. DOI: 10.1016/j.csr.2017.04.002.

Lalli, C.M. \& Gilmer, R.W. (1989). Pelagic Snails: The Biology of Holoplanktonic Gastropod Mollusks. Stanford University Press.

Le Quéré, C., Jackson, R.B., Jones, M.W., Smith, A.J.P., Abernethy, S. et al. (2020). Temporary reduction in daily global $\mathrm{CO}_{2}$ emissions during the COVID-19 forced confinement. Nature Climate Change 10(7): 647-653. DOI: 10.1038/ s41558-020-0797-x.

Lejeusne, C., Chevaldonné, P., Pergent-Martini, C., Boudouresque, C.F. \& Pérez, T. (2010). Climate change effects on a miniature ocean: the highly diverse, highly impacted Mediterranean Sea. Trends in Ecology and Evolution 25(4): 250-260. DOI: 10.1016/j.tree.2009.10.009.

Lischka, S., Stange, P. \& Riebesell, U. (2018). Response of Pelagic Calcifiers (Foraminifera, Thecosomata) to ocean acidification during oligotrophic and simulated upwelling conditions in the subtropical North Atlantic Off Gran Canaria. Frontiers in Marine Science 5(OCT): 1-11. DOI: 10.3389/fmars.2018.00379.

Liu, Z. (2020). Near-real-time monitoring of global $\mathrm{CO}_{2}$ emissions reveals the effects of the COVID-19 pandemic. Nature Communications 11(5172): 1-12. DOI: 10.1038/ s41467-020-18922-7.

Locarnini, R.A., Mishonov, A.V., Baranova, O.K., Boyer, T.P., Zweng, M.M. et al. (2019). World Ocean Atlas 2018, Volume 1: Temperature. In A. Mishonov (Ed.), NOAA Atlas NESDIS 1(81): 52pp.

López-Arellanes, H., Funes-Rodríguez, R., Flores-Coto, C., Zavala-García, F. \& Espinosa-Fuentes, M.L. (2018). Comparison of pteropod assemblages and their relationship with environmental variables in the southern Gulf of Mexico. Journal of Molluscan Studies July: 386-396. DOI: 10.1093/mollus/eyy029.

Manno, C., Bednaršek, N., Tarling, G.A., Peck, V.L., Comeau, S. et al.(2017). Shelled pteropods in peril: Assessing vulnerability in a high $\mathrm{CO}_{2}$ ocean. Earth-Science Reviews 169(August 2016): 132-145. DOI: 10.1016/j.earscirev.2017.04.005.

Menzies, R.J. (1957). Shell-bearing pteropod gastropods from Mediterranean (Cavoliniidae). Pubb. Staz. Zool. Napoli 30: 381-401.

Nishimura, S. (1965). Droplets from the plankton net: XX. "Sea stings" caused by Creseis acicula Rang (Mollusca: Pteropoda) in Japan. Publ. Seto Mar. Biol. Lab. XIII(4): 287290.

Oğuz, T. (2015). Interaction of the Aegean Sea with the Turkish Straits System in Terms of Flow and Water Mass Characteristics. In T. Katağan, A. Tokaç, S. Beşiktepe \& B. 
Öztürk (Eds.), The Aegean Sea: Marine Biodiversity, Fisheries, Conservation and Governance (pp. 40-54). Turkish Marine Research Foundation (TÜDAV).

Oğuz, T. \& Öztürk, B. (2015). Mechanisms impeding natural Mediterranization process of Black Sea fauna. Journal of Black Sea / Mediterranean Environment 17(3): 234-253.

Okuş, E., Sur, H., Yüksek, A., Yılmaz, I., Aslan-Yılmaz, A. et al. (2004). Determining the Biological Diversity of the Coastal Areas of Datça-Bozburun Special Environmental Protection Zone. T.C. Çevre ve Orman Bakanlığı Özel Çevre Koruma Kurumu Başkanlığı. (In Turkish).

Onmuş, O.A. (2002). The distribution of Crecies acicula (Mollusca, Pteropoda) in the Izmir Bay zooplankton. Unpublished master's thesis. Ege University.

Öztürk, B. (2002). The Marmara Sea, a link between the Mediterranean and the Black Sea. In E. Leppäkoski (Ed.), Invasive Aquatic Species of Europe (pp. 337-340). Kluwer Academic Publishers. DOI: 10.1007/978-94-015-99566_34.

Öztürk, B., Doğan, A., Bitlis-Bakir, B. \& Salman, A. (2014). Marine molluscs of the Turkish coasts: An updated checklist. Turkish Journal of Zoology 38(6): 832-879. DOI: 10.3906/ zoo-1405-78.

Parra-Flores, A. \& Gasca, R. (2009). Distribution of pteropods (Mollusca: Gastropoda: Thecosomata) in surface waters (0-100 m) of the Western Caribbean Sea (winter, 2007). Revista de Biología Marina y Oceanografía 44(3). DOI: 10.4067/s0718-19572009000300011.

Pazi, I. (2008). Water mass properties and chemical characteristics in the Saros Gulf, Northeast Aegean Sea (Eastern Mediterranean). Journal of Marine Systems 74(12): 698-710. DOI: 10.1016/j.jmarsys.2008.07.002.

Peijnenburg, K.T.C.A., Janssen, A.W., Wall-Palmer, D., Goetze, E., Maas, A.E. et al. (2020). The origin and diversification of pteropods precede past perturbations in the Earth's carbon cycle. Proceedings of the National Academy of Sciences of the United States of America 117(41): 2560925617. DOI: 10.1073/pnas.1920918117.

Pillai, S. \& Rodrigo, J. (1979). Swarming of Creseis acicula Rang (Pteropoda) in the Palk Bay off Mandapam. Journal of the Marine Biological Association of India 21(1\&2): 178-179.

Roger, L.M., Richardson, A., McKinnon, A.D., Knott, B., Matear, R. et al. (2002). Comparison of the shell structure of two tropical Thecosomata (Creseis acicula and Diacavolinia longirostris) from 1963 to 2009: potential implications of declining aragonite saturation. ICES Journal of Marine Science 69(3): 465-474. DOI: 10.2307/4451315.

Ryan, P.G., Moore, C.J., Van Franeker, J.A. \& Moloney, C.L. (2009). Monitoring the abundance of plastic debris in the marine environment. Philosophical Transactions of the Royal Society B: Biological Sciences 364(1526): 1999-2012. DOI: 10.1098/rstb.2008.0207.

Sakthivel, M. \& Harida, P. (1974). Synchronization in the occurance of Trichodesmium bloom and swarming of
Creseis acicula Rang (Pteropoda) and Penilia avirostris (Cladocera) in the area off Cochin. Mahasagar 7(1 \&2): 61-67.

Sayin, E., Eronat, C., Uçkaç, Ş. \& Beşiktepe, Ş.T. (2011). Hydrography of the eastern part of the aegean sea during the eastern mediterranean transient (EMT). Journal of Marine Systems 88(4): 502-515. DOI: 10.1016/j. jmarsys.2011.06.005.

Schlitzer, R. (2018). Ocean Data View. https://odv.awi.de/

Schneider, A., Wallace, D.W.R. \& Körtzinger, A. (2007). Alkalinity of the Mediterranean Sea. Geophysical Research Letters 34(15). DOI: 10.1029/2006GL028842.

Sitta, K.A., Reed, M., Mortensen, R., Doll, C., Callahan, T. et al. (2018). The influences of nitrogen form and zooplankton grazing on phytoplankton assemblages in two coastal southeastern systems. Limnology and Oceanography 63(6): 2523-2544. DOI: 10.1002/Ino.10957.

Touratier, F. \& Goyet, C. (2011). Impact of the Eastern Mediterranean Transient on the distribution of anthropogenic $\mathrm{CO}_{2}$ and first estimate of acidification for the Mediterranean Sea. Deep-Sea Research Part I: Oceanographic Research Papers 58(1): 1-15. DOI: 10.1016/j. dsr.2010.10.002.

TÜDAV. (2020). Report on Climate Change and Seas. https:// tudav.org/calismalar/iklim-degisikligi/iklim-degisikligive-denizler-raporu/. (In Turkish).

Tuğrul, S., Beşiktepe, Ş.T. \& Salihoğlu, I. (2002). Nutrient exchange fluxes between the Aegean and Black Seas through the marmara sea. Mediterranean Marine Science 3(1): 33-42. DOI: 10.12681/mms.256.

Tunçer, S., Torcu-Koç, H. \& Erdoğan, Z. (2020a). Occurrence of the golden pompano, Trachinotus ovatus (Linnaeus 1758) (Osteichtyes: Carangidae) in Dardanelles, the Sea of Marmara. Natural and Engineering Sciences 5(1): 37-44. DOI: 10.28978/nesciences.691695.

Tunçer, S., Torcu-Koç, H., \& Kanat, R.E. (2020b). Occurence of the Thermophilic Mediterranean Parrotfish Sparisoma cretense (Linneaus, 1758) (Teleostei: Scaridae) in Dikili Bay, Northern Aegean Sea, Turkey. Journal of Anatolian Environmental and Animal Sciences 5(4): 759-764. DOI: 10.35229/jaes.739479.

Türkoğlu, M. (2010). Temporal variations of surface phytoplankton, nutrients and chlorophyll a in the Dardanelles (Turkish Straits System): A coastal station sample in weekly time intervals. Turkish Journal of Biology 34(3): 319-333. DOI: 10.3906/biy-0810-17.

Türkoğlu, M., Baba, A. \& Özcan, H. (2006). Determination and evaluation of some physicochemical parameters in the Dardanelles (Canakkale Strait, Turkey) using multiple probe system and geographic information system. Hydrology Research, 37(3): 293-301. DOI: 10.2166/nh.2006.012.

van der Spoel, S. \& Dadon, J. (1999). South Atlantic Zooplankton. In B. Backhuys (Ed.). Leiden.

Winnes, H., Styhre, L. \& Fridell, E. (2015). Reducing GHG 
emissions from ships in port areas. Research in Transportation Business and Management 17: 73-82. DOI: 10.1016/j.rtbm.2015.10.008.

Yapıcı, S., Filiz, H. \& Bilge, G. (2016). Northwards range expansion of Sparisoma cretense (Linnaeus, 1758) in the Turkish Aegean Sea. Journal of Aquaculture Engineering and Fisheries Research 2(4): 201-207. DOI: 10.3153/jaefr16022.

Zervakis, V., Krasakopoulou, E., Georgopoulos, D. \& Souvermezoglou, E. (2003). Vertical diffusion and oxygen consumption during stagnation periods in the deep North Aegean. Deep-Sea Research Part I: Oceanographic Research Papers 50(1): 53-71. DOI: 10.1016/S0967-0637(02)00144-9.

Zweng, M.M., Reagan, J.R., Seidov, D., Boyer, T.P., Antonov, J.I. et al. (2019). World Ocean Atlas 2018, Volume 2: Salinity. NOAA Atlas NESDIS 2(82): 50. 